\title{
REVISION OF THE GENERA GNOSTUS AND FABRASIA (COLEOPTERA: PTINIDAE)
}

\author{
By John F. Lawrence ${ }^{1}$ and Hans Reichardt ${ }^{2}$
}

The species of Gnostus and Fabrasia are the only myrmecophilous Ptinidae occurring in the New World, although the family is represented in South Africa and Australasia by at least 12 genera of inquilines. Gnostus comprises three species ranging from Bolivia and central Brazil to Florida and the Bahamas and all apparently associated with ants of the genus Crematogaster. The three species of Fabrasia are all South American, and two of these (described below) have been taken with ants of the genus Camponotus.

Gnostus formicicola was described by Westwood (I855) from material collected with ants in Brazil. Although the species bore a distinct resemblance to the Paussidae in the structure of the legs, antennae, and prothorax, Westwood concluded, after a thorough comparative study, that it was "most nearly allied to such of the Xylophaga of Latreille as possess five-jointed tarsi . .." Later authors were more impressed by the specialized features of the species, and it was placed in a distinct family by Gemminger and Harold (1868). Wasmann (I894) and others placed it near the Paussidae, Pselaphidae, Scydmaenidae, or Ectrephidae. Gnostus remained a genus of dubious affinities until Forbes (1926) pointed out the similarities in wing venation and wing-folding pattern to members of the family Ptinidae. In the present study, it was found that the male genitalia of G. formicicola and G. floridanus Blatchley (Figs. I3-14) are of the same general type as that of Fabrasia, Ptinus, Pseudeurostus, Gibbium, and several of the Old World Ectrephinae (Hinton, I94I; Sharp and Muir, I912). The ectrephines have already been placed in the Ptinidae by Wasmann (1916) and will be treated in a forthcoming paper (in preparation).

The genus Fabia was proposed by Martinez and Viana (1964) for a Brazilian species ( $F$. alvarengai), but no mention was made of myrmecophilous habits in the species; the name was later changed to Fabrasia (Martinez and Viana, 1965) because of homonymy. Last year we found specimens of a second species of Fabrasia among the William Morton Wheeler inquiline collection in the Museum of Comparative Zoology, and shortly after this Father Thomas Borg-

\footnotetext{
${ }^{1}$ Museum of Comparative Zoology, Harvard University, Cambridge, Mass.

${ }^{2}$ Departamento de Zoologia, Secretaria da Agricultura, Sao Paulo, Brazil. Manuscript received by the editor January 6, 1966
} 
meier presented us with a specimen representing another undescribed species. This led to a comparative study of ptinid myrmecophiles, part of the results of which are presented below.

Since both Gnostus and Fabrasia have been made the types of subfamilies, it might be well to briefly discuss the classification and possible evolutionary origins of the two groups. Gnostus and Fabrasia differ considerably from any other group myrmecophilous ptinids in general form and in the presence of fully developed wings and humeral callosities; in this respect they are both similar to certain species of the genus Ptinus. They do resemble the Old World myrmecophiles in the modifications of the antennae, presence of glandular areas or trichomes, elongation of the clypeus, and reduction of body hairs or scales, so that the surface appears shiny; most of these similarities probably represent adaptations associated with myrmecophilous habits, and similar trends are found in the Paussidae, the clavigerine Pselaphidae, and other groups of inquilines. Although Gnostus and Fabrasia are set apart from the other genera,
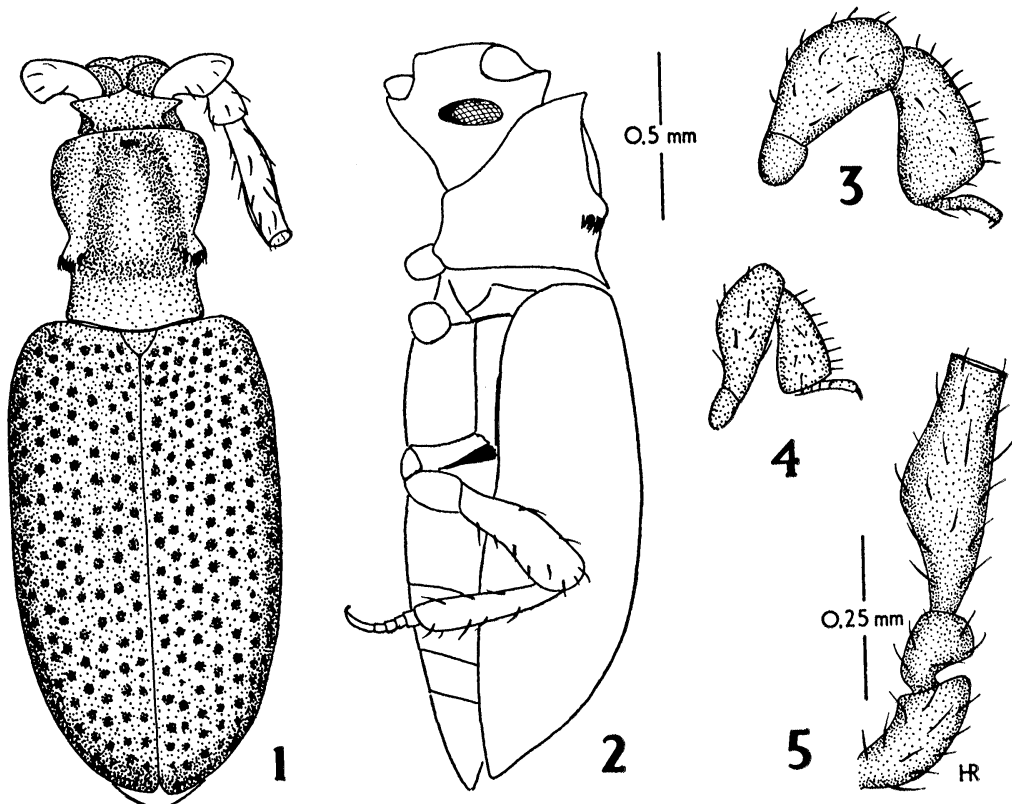

Figs. 1 - 5. Gnostus floridanus Blatchley (from Plantation Key, Florida), Fig. 1, dorsal view; Fig. 2, lateral view; Fig. 5, antenna; Gnostus meinerti Wasmann (from Barro Colorado Island, Panama), Fig. 3, hind leg; Gnostus formicicola Westwood (lectotype), Fig. 4, hind leg. 
they are also quite distinct from one another, and it would be difficult to derive them from a common stem. The kinds of adaptive structures occurring in the two groups are entirely different. The glandular structures in Gnostus consist of trichomes on the pronotum, while those of Fabrasia consist of scattered pores on the elytra and a brush of hairs on either side of the distal articulation of the hind femur. The legs of Gnostus may be flattened and expanded like those of certain Paussidae, while the species of Fabrasia have peculiarly enlarged and club-like femora, which to our knowledge are unknown in any other beetle group. Characters of the head, antennae, prosternum, abdomen, and genitalia show similar differences. We think that the two genera were probably independently derived from Ptinus-like ancestors, perhaps early in the evolution of the family. Since most of the ant host species appear to nest in woody habitats, the beetles may have evolved from subcortical scavengers which had originally been derived from wood-boring ancestors (Crowson, 1955). It appears reasonable to retain the subfamilies Gnostinae and Fabrasiinae for the present, but in a revision of the family they may well be reduced to tribal rank within the Ptininae.

In 1962, Costa Lima described another apparently myrmecophilous ptinid, Plaumanniola sanctaecatharinae, which he made the type of another subfamily. The type of this species has been examined, and it was found to belong to the family Scydmaenidae (Lawrence and Reichardt, 1966).

\author{
Gnostus Westwood \\ (Figs. $\mathrm{I}-5, \mathrm{1} 3-\mathrm{I} 5$ )
}

Gnostus Westwood, 1855, Trans. Ent. Soc. London, (2)3: 90. (TYPE SPECIES: Gnostus formicicola Westwood, by monotypy).

DESCRIPTION : Form elongate, convex; vestiture of short, suberect, sparsely distributed, fine hairs; surface shiny. Head strongly declined, only partly visible from above; vertex concave, forming a broad transverse impression, joined laterally on each side to a deep and narrow, oblique groove extending to the eye below; eyes lateral, relatively small, elongate and carinate; antennal fossae relatively deep, located well above the eyes, separated by a sharp median carina; clypeus subtriangular, almost as long as wide, strongly tumid, and emarginate at apex; labrum inflexed and concave. Antennae (Fig. 5) 3-segmented, relatively short (not reaching base of pronotum); segment I elongate, slightly curved, expanded towards apex; II about half as long as I, inserted beneath the latter, terminal segment almost twice as long as I and II together, expanded ventrally at middle and truncate apically, the tip excavate and filled with short hairs. 
Pronotum longer than wide, constricted basally; anterior angles rounded; disc somewhat flattened dorsally, with two more or less parallel longitudinal grooves, extending from two anterior pores posteriorly to a broad and deep, transverse impression, which is bordered on each side by two opposing, curved trichomes. Scutellum small, semicircular. Elytra more than twice as long as pronotum, almost twice as wide at humeri as pronoum at base; sides more or less parallel, expanded and broadly rounded apically; humeral callosities distinct; disc slightly convex dorsally, steeply sloping laterally; each elytron with 9 rows of fine punctures bearing short, suberect, fine, yellow hairs; apices of elytra individually rounded but only barely divergent. Hindwings fully developed. Prosternum before coxae flat, fairly long, intercoxal process laminate and depressed, so that the elongate coxae are almost touching. Mesosternum shorter than prosternum; mesocoxae separated by less than 0.25 times coxal width. Metasternum less than 0.50 times as long as wide and slightly longer than mesosternum, convex, median suture absent; metacoxae strongly transverse, separated by less than 0.20 times coxal width. Abdomen about as long as wide at base, strongly convex anteriorly; first 3 segments fused, the sutures between them indicated only laterally; 4th segment very narrow. Legs (Figs. 2-4) relatively short and simple; trochanters elongate-oval; femora and tibiae narrow and slightly flattened ( $G$. floridanus) or strongly flattened and expanded (G. formicicola and G. meinerti); tarsi short, the first 4 tarsomeres subequal. Male genitalia (Figs. I3-I4) of the general type of Ptinus with median lobe articulating dorsally with bases of parameres; basal piece relatively large, parameres very narrow, curved, converging apically. Total length: $1.70-2.53 \mathrm{~mm}$.

Distribution: (Fig. I5): South America (Brazil, Bolivia, and Venezuela), Panama, Florida, and the Bahamas.

The relatively narrow and elongate body form, presence of distinct humeral callosities, and well developed scutellum and hindwings, will distinguish Gnostus from the majority of ptinid genera. From Ptinus and Niptinus it differs by the structure of the clypeus (which is more elongate), the lack of a metasternal suture, narrower pronotum, and the modifications of legs and antennae. Gnostus is easily separated from Fabrasia by the 3-segmented antennae, position and size of eyes, longer and narrower prothorax, shorter legs, absence of metasternal suture, and partial obliteration of the first two abdominal sutures. The genus is most closely related to Ptinus and Fabrasia.

All of the species of Gnostus appear to be associated with ants of the genus Crematogaster, and in the compilation below, at least five 
species of this genus are involved. To our knowledge, no Gnostus has been collected with ants of any other group, and the record of $G$. meinerti from a termite nest needs verification. According to Professor E. O. Wilson (personal communcation), only one specimen of $G$. floridanus was found in a colony of $C$. ashmeadi Mayr on Plantation Key, although the ant is very common at that locality. Bates, on the other hand, as quoted in Westwood (I855), states that the formicaria of Crematogaster victima Smith almost invariably contained one, or at most two, Gnostus formicicola.

\section{KeY TO THE SPECIES OF GNOSTUS}

I. Tibiae only very slightly compressed, about 4 times as long as wide at apex (Fig. 2); longitudinal grooves of pronotum deep; Florida and Bahamas floridanus Blatchley

- Tibiae strongly compressed and expanded apically, only 2 times as long as wide at apex (Figs. $3-4$ ); longitudinal grooves of pronotum very shallow; South America and Panama .... 2

2. Posterior tarsus, when retracted, almost completely hidden in apical groove of tibia (only tarsal claws visible); longitudinal grooves of pronotum converging apically; Venezuela and Panama meinerti Wasmann

- Posterior tarsus, when retracted, not completely hidden in apical groove of femur (5th tarsomere and claws visible); longitudinal grooves of pronotum subparallel; Brazil and Bolivia formicicola Westwood

\section{Gnostus formicicola Westwood}

(Fig. 4)

Gnostus formicicola Westwood, 1855, Trans. Ent. Soc. London, (2) 3: 92, pl. 8, figs. 1-21.

TYPE DATA: "Habitat in Brasilia, apud Santarem, in nidis Myrmicae (Crematogastris) victima, Smith. D. Bates. In Mus. Britann., \&c." Lectotype, by present designation, + , with the following labels: I) "Co-type, Westwood Trans. Ent. Soc. I855. p. 90. T. 8. Coll. Hope Oxon." (red border), 2) "W Amazon Bates" (diamond-shaped), 3) "Gnostus formicicola Westwood B2 Bates," 4) "Type Col: 235 Gnostus formicicola Westw. Hope Dept. Oxford" (Black border); deposited in the Hope Department of Entomology, Oxford, England.

Specimens Examined: bolivia: La Paz, Mapiri, iv - ix. 1925, G. L. Harrington col. ( Iㅇ, USNM). BRAZIL: Mato Grosso, Utiariti, $325 \mathrm{~m}$, viii.5.196r, K. Lenko col., with Crematogaster prope 
brasiliensis Mayr (W. W. Kempf det.) (2 exx., CDZ) ; Para, Santarem, 5463 ( Iㅇ, BM) ; Villa Nova, 5575 ( I $0^{\star}, \mathrm{BM}$ ); Amazonas, Sao Paulo [de Olivenca] ( I ex., BM) ; "Amazon, Bates" (Iㅇ, BM).

This species was previcusly known only from the several specimens examined by Westwood; the only available specimen which can be assumed to be from the original type series is designated as lectotype above. Four other specimens in the British Museum are apparently not from the Bates material examined by Westwood. Gnostus formicicola seems to have a fairly wide distribution south of the Rio Amazonas. It appears to be very closely related to the northern $G$. meinerti, and only a few minor characters separate them. Since the two species are allopatric on the basis of presently known material, it is quite possible that they represent geographical races. Because of the paucity of available specimens, the lack of intermediate forms, and the absence of noticeable variation within either population, we prefer to retain them as distinct species. The original series of $G$. formicicola was taken from the nests of Crematogaster victima Smith, but Lenko has recently collected it in the colony of a Crematogaster near brasiliensis Mayr.

\section{Gnostus meinerti Wasmann}

(Fig. 3)

Gnostus meinerti Wasmann, 1894, Kritisch. Verzeich.: 121, 216.

TYPE DATA: "Ein Exemplar von Dr. F. Meinert am Rande des Weges von las Trincheras nach Valencia (Venezuela) im Nest von Cremastogaster limata Sm. am 5. Nov. I891 entdeckt." According to Wasmann the type is deposited in "Collect. Mus. Univ. Hafn.;" not examined.

Specimens Examined: panama: Canal Zone, Barro Colorado Island, vii.I 7.1924, G. C. Wheeler col., with Crematogaster limata dextella Santschi (Santschi det.) (2 exx., USNM, CNHM); same locality, vi.I923, R. C. Shannon col., ex stomach of anteater (Tamandua tetradactyla chiriquensis) (2oㅇ, USNM) ; Erwin Island, vi.r7.1923, R. C. Shannon col. ( I ex., USNM); Gatun Lake, Barro Colorado Island, Wheeler col., with Coptotermes niger Snyder ( I ex. USNM).

Although Wasmann's type was not examined, specimens of the Panama population agree well enough with the description to be considered conspecific with meinerti from Venezeula. The species seems to be restricted to northern South America, but further records will be needed to ascertain the limits of its distribution. Both of the known populations of this beetle have been collected in associa- 



LaWrence and ReichardT - Ptinidae 
tion with Crematogaster limata Smith. The close relationship to $G$. formicicola has been discussed under that species.

\section{Gnostus floridanus Blatchley}

(Figs. I, 2, 5, I3, I4)

Gnostus floridanus Blatchley, 1930, Ent. News, 36: 111-112, fig. 1.

TYPE DATA: "Type a unique (sex undetermined) in the author's collection, taken near Dunedin, Florida, March 7, 1927" Location of type apparently in Blatchley Collection, Purdue University, Lafayette, Indiana; not examined.

Specimens Examined: Florida: Plantation Key, vi.i7.58, E. O. Wilson col., with Crematogaster ashmeadi Mayr. BAHAMAS: New Providence, Clifton Point, iv.2.65, R. W. Hamilton \& B. D. Valentine col., with Crematogaster sanguinea lucayana Wheeler (compared with type in the M. G. Z. collection).

Gnostus floridanus was previously known only from the type locality, but the data presented above indicates that it may be more widespread in Florida and the West Indies. Blatchley's specimen was beaten from spanish moss, but this species, like its congeners appears to be found only with ants of the genus Crematogaster. It is easily distinguished from formicicola and meinerti by the characters given in the key, although all three species are fairly similar.

\section{Fabrasia Martinez and Viana}

(Figs. 6- I2, I 5)

Fabia Martinez and Viana, 1964, Neotropica, 10(31): 8, not Dana, 1851. (TYPE SPECIES: Fabia alvarengai Martinez and Viana, by original designation).

Fabrasia Martinez and Viana, 1965, Neotropica, 11(34): 18.

DESCRIPTION : Form elongate, strongly convex; vestiture of short, suberect, sparsely distributed bristles; surface shiny. Head strongly declined, only partly visible from above; vertex slightly convex, with elongate, narrow, median impression; eyes lateral, well developed, rounded; antennal fossae broad and shallow, located between eyes, separated by a slight tumidity ( $F$. alvarengai) or a distinct carina ( $F$. borgmeieri and $F$. wheeleri); clypeus subtriangular, almost as

Explanation of Plate 2

Fabrasia borgmeieri. n. sp. (holotype), Fig. 6, dorsal view; Fig. 7, lateral view; Fabrasia wheeleri, n. sp. (paratype + ), Fig. 8, dorsal view; Fig. 9, lateral view. 
long as wide, strongly tumid, sharply inflexed and emarginate at apex; labrum flat. Antennae I I-segmented, extending at least to elytral humeri, moniliform to subserrate, the distal segments slightly wider at apices; segment I oval to oblong, 2 times as long as II which is subglobular, III narrow and elongate, IV - VIII decreasing in length, IX - XI increasing in length; terminal segment distinctly expanded and truncate apically, the tip excavate and filled with short hairs. Pronotum slightly transverse, constricted basally; anterior angles produced laterally forming 2 sharp flanges which partly conceal eyes; disc with 6 medial tubercles in a transverse row. Scutellum small, semicircular. Elytra more than 3.50 times as long as pronotum; sides subparallel, but distinctly constricted just anterad of middle; humeral callosites well developed; disc somewhat flattened dorsally on either side of suture, steeply sloping laterally; each elytron with 6 or 8 deep lateral striae and 2 dorsal striae, which may be obsolete except at base; punctation dual, consisting of small, setiferous punctures, which are seriate and located in the interstices, and larger, shallow ones, which contain glandular pores and are located within the striae; glandular pores in the lateral constrictions larger and closer together, giving the appearance of a transverse band; apices of elytra slightly to strongly divergent. Hindwings fully developed. Prosternum before coxae tumid, fairly short, intercoxal process long, narrow but not laminate; procoxae separated by less than 0.25 times coxal width. Mesosternum subequal to prosternum; mesocoxae separated by about 0.33 times coxal width. Metasternum about 0.50 times as long as wide and r.5O times as long as mesosternum, strongly convex and rounded, median suture present; metacoxae transversely oval, separated by 0.50 times coxal width. Abdomen r.25 times as long as wide at base, strongly convex anteriorly, the sutures all distinct. Legs (Figs. 7, 9) long and highly modified; trochanters elongate-oval; femora enlarged and club-like distally, the hind femur greatly enlarged and irregularly formed, its tibial articulation with a dense brush of yellow hairs on each side; front and middle tibiae elongate, the hind tibia short and formed as in figure; first tarsomere more than 2 times as long as 2nd in front and middle tarsi, more than 3 times as long in hind tarsus. Male genitalia (Figs. ro - I2) of the general type of Ptinus with median lobe articulating dorsally with

\section{Explanation of Plate 3}

Fabrasia wheeleri, n. sp. (paratype $\hat{\delta}$ ), aedeagus, Fig. 10, lateral view; Fig. 11, ventral view; Fig. 12, ventral view (with basal piece removed); Gnostus floridanus Blatchley (from Clifton Point, Bahamas), aedeagus, Fig. 13, ventral view; Fig. 14, ventral view (with basal piece removed). 
Psyche, 1966

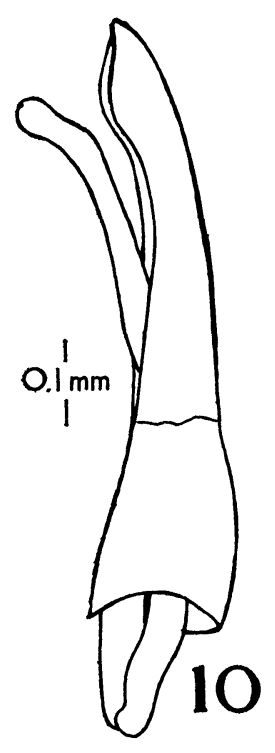

Vol. 73, Plate 3
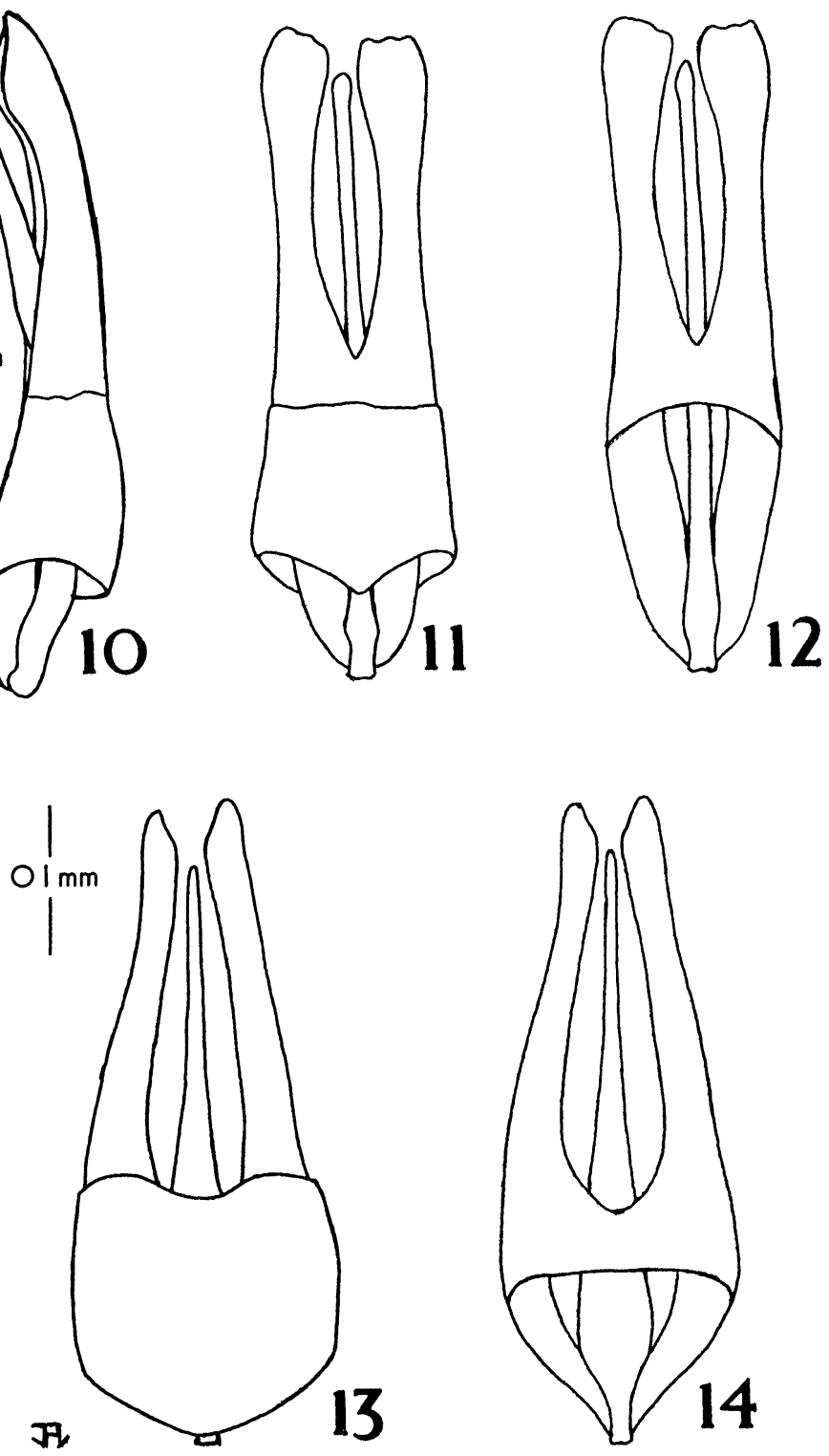

I.AWkence and Reichardt - Ptinidae 
bases of parameres; basal piece relatively small, parameres fairly broad and straight, slightly expanded at apices. Total length: $2.87-$ $3.32 \mathrm{mim}$.

Distribution (Fig. I5): South America (Brazil and Colombia).

Fabrasia may be distinguished from the majority of ptinid genera by the body form, distinct humeral callosities, scutellum, metasternal suture, and fully developed hindwings. It differs from Ptinus and Niptinus by the clypeal structure, elytral constriction, glandular pores, and modifications of legs and antennae. It may be separated from Gnostus by the characters given under that genus. This genus, like Gnostus, seems to be related to Ptinus.

Although the type species has not been collected with ants, both $F$. borgmeieri and $F$. wheeleri have been taken in the nests of species of Camponotus. It is interesting to note that the two ant hosts belong to the same subgenus (Myrmothrix), but more material will be needed to consider this anything but an accident of sampling. Camponotus bugnioni, the host of Fabrasia wheeleri, is known only from near the type locality in northern Colombia, while $C$. renggeri, the host of $F$. borgmeieri, is a common, widespread species, occurring from northern Argentina to northern Brazil. Nothing is known at present of the habits of these myrmecophiles; a study of their behavior might be particularly fruitful, considering the unique specialized structures which they possess.

Key to the species of Fabrasia

I. Elytra with 8 lateral striae, 2 dorsal striae visible for their entire lengths; discal tubercles of pronotum conical and sharp; apices of elytra only slightly divergent; hind tibia without pencil of black hairs; elytral bristles very short; larger species (3.I 7 $3.30 \mathrm{~mm}$.) ; Colombia wheeleri n. $\mathrm{sp}$.

- Elytra with 6 lateral striae, 2 dorsal striae obsolete except at base; pronotal tubercles low and rounded; apices of elytra strongly divergent; hind tibia with $\mathrm{I}$ or 2 pencils of black hairs; elytral bristles longer; smaller species (2.873.1 $5 \mathrm{~mm}$.)

2. Hind tibia with a single pencil of hairs on outer side; clypeus distinctly swollen; antennal fossae joined by a transverse channel; Brazil (Rio Grande do Norte)

alvarengai Martinez and Viana

- Hind tibia with 2 pencils of hairs, one on inner and one on outer side; clypeus not swollen; antennal fossae separated by a median carina; Brazil (Goias) ................. borgmeieri n. sp. 


\section{I abrasia alvarengai (Martinez and Viana)}

Fabia alvarengai Martinez \& Viana, 1964, Neotropica, 10(31): 9, figs. 1-3. Fabrasia alvarengai (Martinez \& Viana), 1964, Neotropica. 11 (34): 18.

TYPE DATA: “. . . I holotipo de Brasil, Rio Grande do Norte, Natal, VI-I95 I (Mi. Alvarenga-leg.), en la coleccion Moacir Alvarenga de Rio de Janeiro." Holotype examined. This species is represented by a single specimen whose abdomen is missing so that the determination of sex is impossible.

\section{Fabrasia borgmeieri, new species}

(Figs. $6-7$ )

DESCRIPTION: Reddish-brown with dark brown spots on elytra; clothed with short yellowish bristles, which are longer on elytra and more concentrated in median constriction, giving the appearance of a transverse band on each side. Head with vertex shallowly impressed, post-antennal ridges weakly developed, antennal fossae relatively shallow and separated by a weak, somewhat flattened ridge; clypeus tumid, but not swollen as in alvarengai; surface coarsely, densely and shallowly punctate and granulate. Antennae almost 3 times as long as pronotum; segment I I.57 times as long as wide, expanded at apex. Pronotum 0.79 times as long as wide at base, anterior angles moderately produced, the sharp flanges only slightly longer than medio-lateral tubercles, which are sharp and conical, the other discal tubercles low and rounded; surface rugosely punctate and granulate, as is scutellum, and clothed with short yellowish bristles. Elytra $\mathrm{I} .94$ times as long as wide at base and $3.8 \mathrm{I}$ times as long as pronotum; base with large and rounded humeral callosities and a low rounded elevation on each side between callosity and suture; dorsal striae obsolete except at base, lateral striae 6 in number, very deep in the vicinity of the medial constriction, where the glandular pores are larger and closer together; elytral apices strongly divergent and narrowed, forming 2 triangular processes; surface smooth and shiny, clothed with suberect yellowish bristles, which form brushes laterally in between the pores. Hind legs as in alvarengai, but the tibia with a longer pencil of black hairs on outer side and a shorter one on inner side. Abdomen strongly convex anteriorly, but not impressed mesially. T'otal length: $2.87 \mathrm{~mm}$.; greatest width (across humeral callosities) : I.I2 $\mathrm{mm}$.

TYPE DATA: Holotype, probably o , Campinas, Goias, Brazil, ii.I964, Schwarzmaier col., with Camponotus (Myrmothrix) renggeri Emery

(T. Borgmeier, det.). Holotype deposited in the Departamento de Zoologia, Secretaria da Agricultura, São Paulo, Brazil. 
$F$. borgmeieri is very similar in general appearance to $F$. alvarengai, sharing with it several characters (given in key) which are not found in $F$. wheeleri. F. borgmeieri is easily distinguished from alvarengai by the presence of a ridge between the antennal fossae, 2 pencils of hairs on the hind tibia, somewhat shorter antennae, and a less swollen clypeus. Since the specimen of alvarengai cannot be sexed, it has occurred to us that the two forms may represent male and female of a single species; the two forms are, however, separated by several characters of the type that are not involved in sexual dimorphism elsewhere in the Ptinidae. The two species are closely related, and when more material is studied, they may prove to be geographic races, which, like Gnostus formicicola and $G$. meinerti, occur on cither side of the Rio Amazonas.

Fabrasia wheeleri, new species (Figs. $8-\mathrm{I} 2$ )

DESCRIPTION : Reddish-brown with blackish elytral spots, which are larger and fewer in number than in borgmeieri; clothed with very short yellowish elytral bristles; elytra with accumulations of white



Fig. 15. Geographic distribution of the species of Gnostus and Fabrasia. 
waxy secretion on each side in the constriction, giving the appearance of a transverse band. Head with vertex deeply impressed, post-antennal ridges well developed and sharply defined, the antennal fossae deeper and separated by a sharp carina; clypeus tumid but not swollen; more distinctly inflexed than in borgmeieri; surface very coarsely, densely, and deeply punctate. Antennae about 2.50 times as long as pronotum; segment I I.33 times as long as wide, subglobular. Pronotum 0.76 times as long as wide at base, anterior angles strongly produced, the sharp flanges distinctly longer than the medio-lateral tubercles, which are sharp and conical, the other medial tubercles higher and sharper than in borgmeieri, 2 comma-shaped antero-mesal longitudinal ridges bordering a median impression which extends to anterior edge; surface very coarsely and densely punctate, as is scutellum, and clothed with yellowish bristles, which are finer and longer than those on elytra. Elytra I.93 times as long as wide at base and 3.77 times as long as pronotum; base with humeral callosities strongly developed and somewhat carinate, without anteromesal elevations, but with a deep puncture on either side of the suture; dorsal striae distinct for their entire lengths, lateral striae 8 in number, containing glandular pores as in borgmeieri, which are also concentrated in the constriction; elytral apices only slightly divergent and rounded. Hind legs as in borgmeieri, but lacking a pencil of black hairs on the tibia. Abdomen of male with a distinct median impression on the first two visible sternites. Aedeagus (of paratype) elongate, basal piece subquadrate, subangulate basally, tegmen deeply cleft apically forming 2 fairly narrow and straight lateral lobes or parameres which are expanded and setose at their tips; median lobe narrow and elongate, curved dorsally at apex and at base, where it is attached to base of tegmen (Figs. IO - I2). Total length: 3.I 7 $3.30 \mathrm{~mm}$. (type $3.17 \mathrm{~mm}$.) ; greatest width (across humeral callosities) : $\mathrm{r} .27$ - $1.38 \mathrm{~mm}$. (type $\mathrm{r} .27 \mathrm{~mm}$.).

TYPE DATA: Holotype, $\sigma^{\star}$, paratype, $\sigma^{\star}$, and paratype, + , Sevilla, Magdalena, Colombia, vi.I2.I927, G. Salt col. (No. N343), with Camponotus (Myrmothrix) bugnioni Forel (compared with cotype in the M.C.Z. collection). Holotype and paratype $o$ deposited in the Museum of Comparative Zoology, Cambridge, Mass. M.C.Z. N. 31200; paratype $\sigma^{\star}$ deposited in the Departamento de Zoologia, Secretaria da Agricultura, São Paulo, Brazil.

Fabrasia wheeleri is easily distinguished from the other two species by its larger size, sharper pronotal tubercles, different clypeal structure, shorter pubescence, and the absence of pencils of hairs on the hind tibia. It certainly seems to be more distantly related to either alvarengai or borgmeieri than these two are to each other. The 
species is named in honor of Professor William Morton Wheeler, renowned authority on ants and their inquilines.

\section{Acknowledgments}

The authors would like to express their sincere thanks to the following institutions and individuals for the loan of specimens in their care: J. F. Gates Clarke, T. J. Spilman, and J. M. Kingsolver, United States National Museum (USNM), Washington, D. C.; H. S. Dybas, Chicago Natural History Museum (CNHM), Chicago, Ill.; J. Balfour-Browne, British Museum (Natural History) $(B M)$, London, England; E. Taylor, Hope Department of Entomology, Oxford, England; A. Martinez, Buenos Aires, Argentina; M. A. Vulcano, K. Lenko and W. C. A. Bokerman, Departamento de Zoologia, Secretaria da Agricultura, (CDZ), Sao Paulo, Brazil; R. W. Hamilton and B. D. Valentine, Ohio State University, Columbus, Ohio; M. Alvarenga and T. Borgmeier, Rio de Janeiro, Brazil. For determination of ants and other information, special thanks are given to R. W. Taylor and E. O. Wilson, Harvard University, Cambridge, Mass. and to W. W. Kempf, São Paulo, Brazil.

Blatchley, W. S.

\section{Literature Cited}

1930. On a family of Coleoptera new to the fauna of North America with description of one new species (Gnostidae). Ent. News, 41: 108-112, 1 fig.

Costa Lima, A. DA

1962. Micro-coleoptero representante da nova subfamilia Plaumanniolinae (Col., Ptinidae). Rev. Bras. Biol., $22(4): 413-418$, 4 figs.

Crowson, R. A.

1955. The natural classification of the families of Coleoptera. Lloyd, London. 187 pp., 212 figs.

Dana, J. D.

1851. Conspectus crustaceorum quae in orbis terrarum circumnavigatione, Carolo Wilkes e classe Reipublicae Foederatae duce, lexit et descripsit. [part]. Proc. Acad. Nat. Sci, Phil., 5: 247-254, 267-272.

Fories, W. T. M.

1926. The wing folding patterns of the Coleoptera. Jour. New York Ent. Soc., 34: 42-68, 91-139, pls. 7-18.

Gemminger, M. \& E. Von Harold

1868. Catalogus Coleopterorum hujusque descriptorum synonymicus et systematicus. Tom. II. Dytiscidae . . . Scaphidiidae. Gumm. Monaco. pp. 425-752.

Hinton, H. E.

1941. The Ptinidae of economic importance. Bull. Ent. Res., 31(4): 331-381, 59 figs. 
Lawrence, J. F. \& H. Reichardt

1966. The systematic position of Plaumanniola Costa Lima (Coleoptera: Ptinidae) Coleopt Bull. (in press).

Martinez A. \& M. J. Viana

1964. Una nueva subfamilia de coleopteros (Ptinidae; Fabiinae). Neotropica, $10(31): 7-14,3$ figs.

1965. Una caso de homonimia en Ptinidae (Coleoptera). Neotropica. $11(34): 18$.

Sharp, D. \& F. MUir

1912. The comparative anatomy of the male genital tube in Coleoptera. Trans. Ent. Soc. London, 1912: 477-642, pls. 42-78.

WASMANN, E.

1894. Kritisches Verzeichniss der myrmekophilen und termitophilen Arthropoden. Dames, Berlin. xiii $+231 \mathrm{pp}$.

WASMANN, E.

1916. Wissenschaftliche Ergebnisse einer Forschungsreise nach Ostindien. ... V. Termitophile und myrmecophile Coleopteren ... Zool. Jahrb., 39: 169-210, pls. 4-5.

Westwood, J. O.

1855. Description of a new genus of coleopterous insects inhabiting the interior of ants' nests, in Brazil. Trans. Ent. Soc. London, (2) 3 : 90-94, pl. 8. 

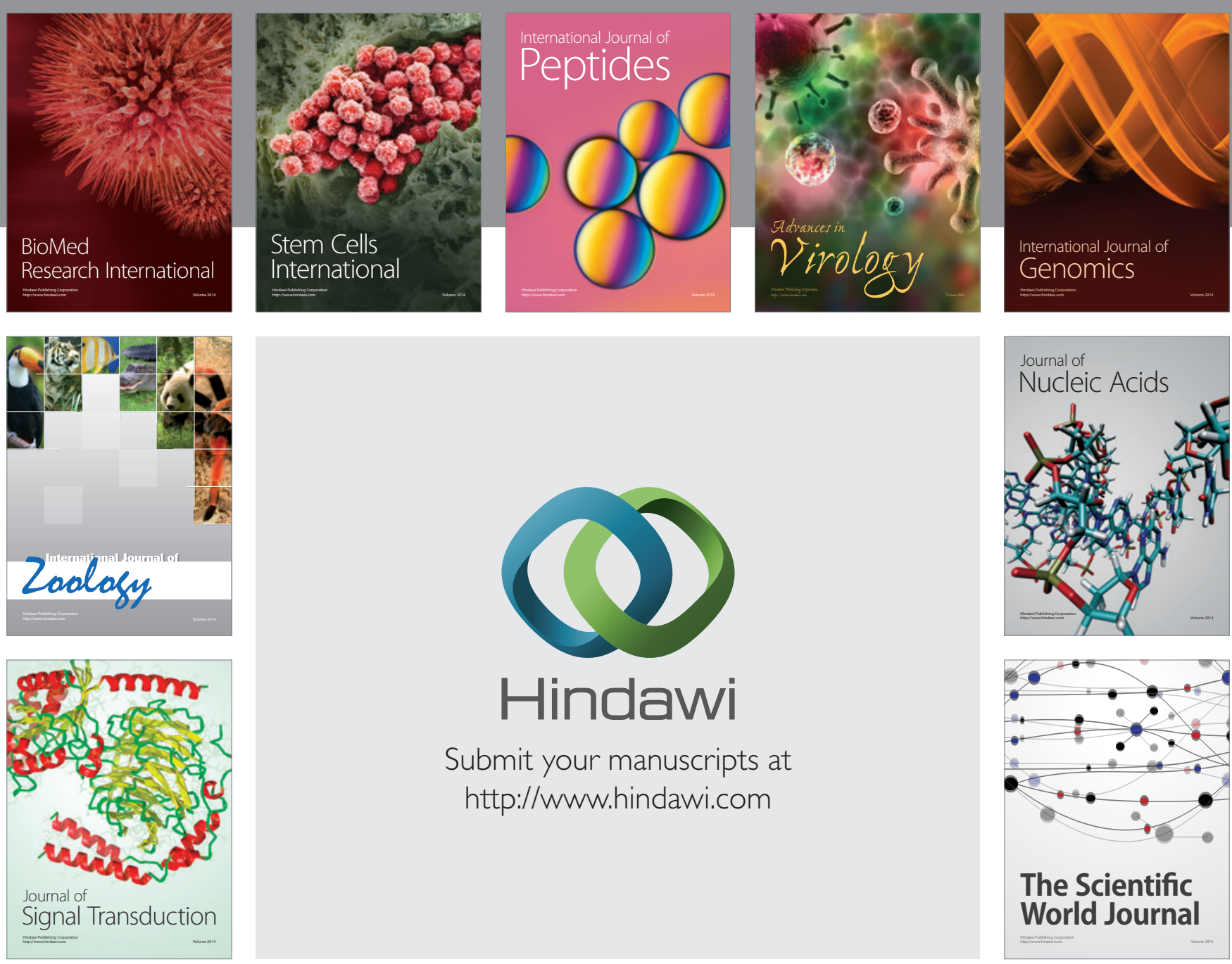

Submit your manuscripts at

http://www.hindawi.com
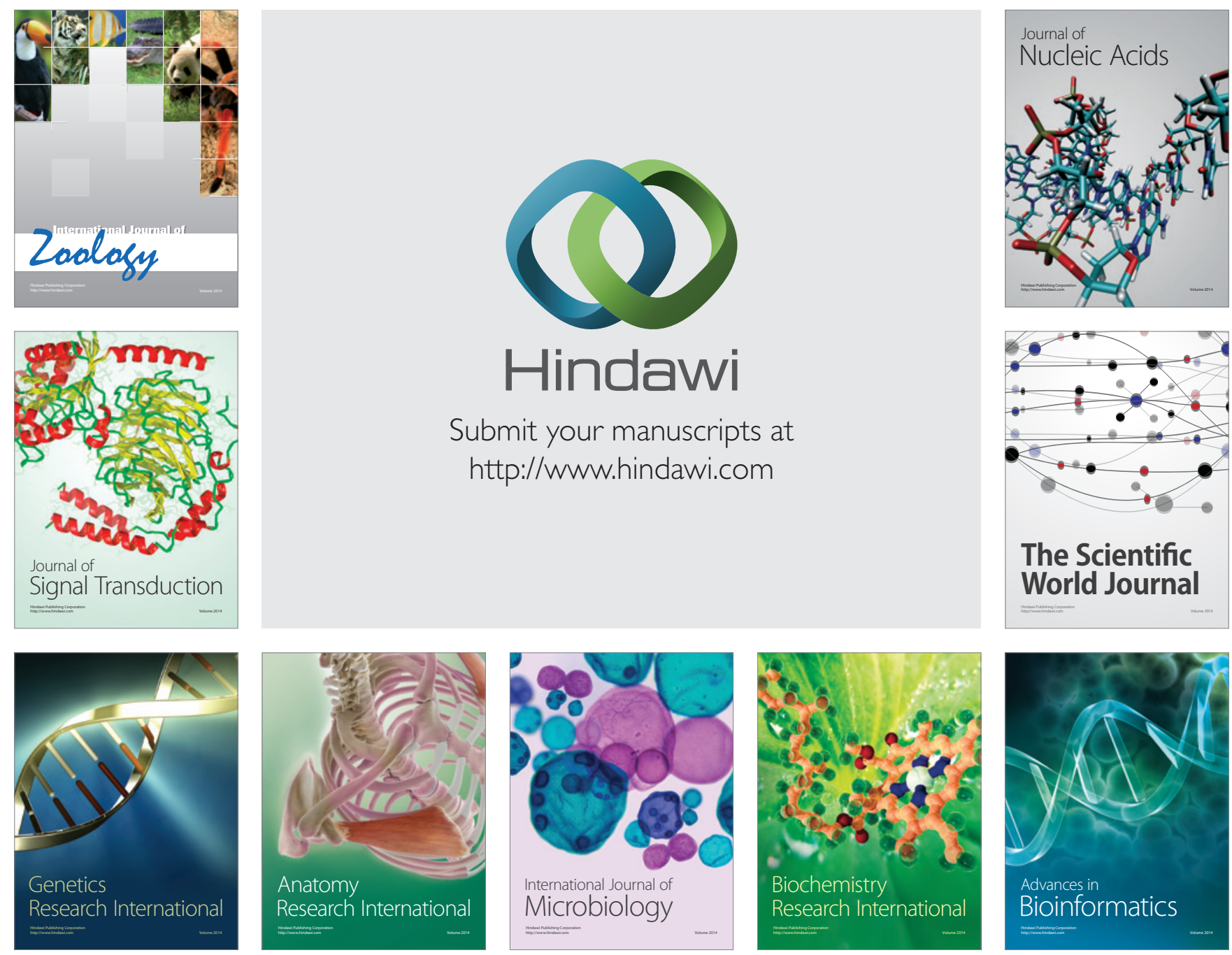

The Scientific World Journal
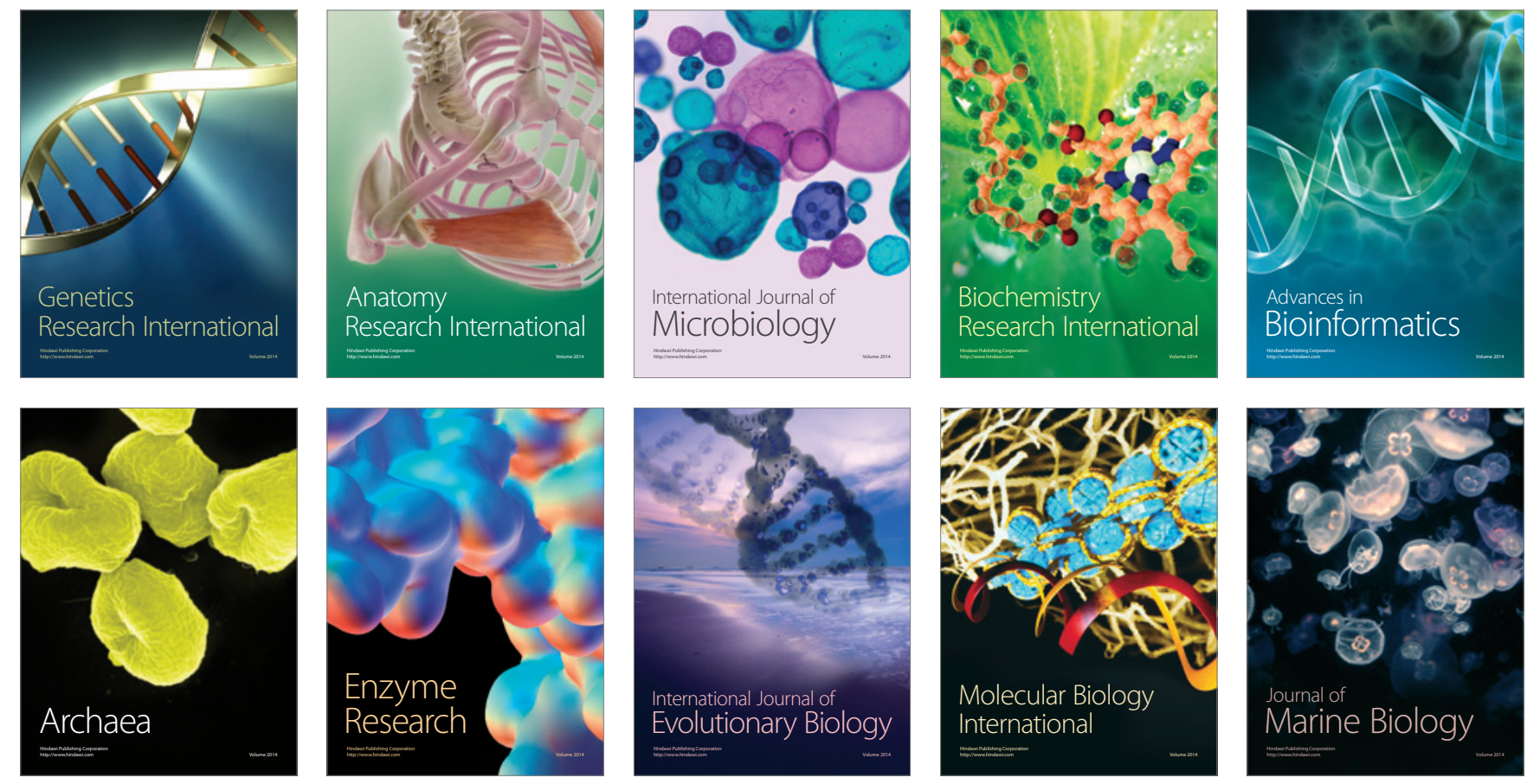